\title{
CONSELHEIRO FRANCISCO DE PAULA RODRIGUES ALVES
}

Da pena do estudante Francisco de Paula Rodrigues Alves (1866-1870) nada menos de sete dissertações estão carinhosamente conservadas na Biblioteca da Faculdade, salvas do incêndio de 1880.

Todas muito interessante, em estilo claro, demonstrando acurado estudo, senso jurídico $e$ grande independência e opinião.

Dentre elas cumpre destacar as de DIREITO NATURAL, DIREITO ADMINISTRATIVO E DIREITO DAS GENTES - em que mais se vislumbram as aptidões do futuro homem público. Principalmente, esta última, versada durante a guerra contra o Paraguay (Téses "As guerras preventivas são contrarias à verdade, $\dot{a}$ razão $e \dot{a}$ justiça") é já o trabalho de um futuro estadista.

Da vida do Conselheiro Rodrigues Alves já disse, em discurso proferido em 15 de março de 1932, o professor Cardozo de Mello Neto.

Dessa oração, transcrevemos os seguintes trechos:

"O prêmio que ora vos é conferido, traz o nome de Rodrigues Alves. Tomai-o como paradigma, tanto na vida pública quanto na do vosso lar; e podereis caminhar serenos, firmes e resolutos pela existência afóra. 
Vêde-o, modesto filho de Guaratinguetá, desconhecido num colégio da Côrte que, por essa época, reunia os filhos dos grandes do 2. Império - primeiro estudante do Colégio Pedro II. E" Joaquim Nabuco, seu condiscipulo, quem o testemunha numa passagem da "Minha Formação: "Filho do presidente do Conselho, foi para mim uma vibração de amor próprio mais forte do que teria sido, imagino, a do primeiro prêmio que o nossso camarada Rodrigues Alves tirava todos os anos"

Vêde-o a seguir nesta Academia, na primeira linha duma turma memoravel - a de Ruy Barbosa e Castro Alves, de Joaquim Nabuco e Aureliano Coutinho, de Sancho de Barros Pimentel $e$ Afonso Penna.

Por essa época, aqui se fazia politica, a verdadeira politica, nấo aquela que mais tarde se entende chamar a "politica acadêmica" isto é, a divisão dos estudantes em grupos, sem qualquer diferenciação de ideal ou de tendências, mas a politica dos tradicionais partidos do Império.

A maior honra estava no lugar de redatorchefe da "Imprensa Acadêmica", ocupado por um bacharelando. Conservador, Rodrigues Alves disputou-o a Afonso Penna, liberal. Empataram. $E$ o jornal teve esse ano, por exeção, dois redadatores chefes.

Fóra da Academia, era ele um dos mais assiduos colaboradores da "Opinião Conservadora", órgão do Partido. Tanto aí se distinguiu, que João Mendes, o velho, que dirigia, então, a imprensa do Partido, entendeu do seu dever apresentá-lo ao público da província como "digno do melhor apreço pelo seu carater sisudo, inteligência cultivada e idéas sans" João Mendes, com 
sua acuidade, descobrira no jovem bacharel, futuro homem público.

Ei-lo em Guaratinguetá, sua terra natal. Começa, então, para só terminar com a morte, a vida politica de Rodrigues Alves.

São 50 anos de dedicação ininterrupta ao interesse público. Durante o Império: deputado provincial, deputado geral, presidente da província de S. Paulo, Conselheiro honorário d'Estado, tudo antes dos 40 anos. Na República: deputado $\dot{a}$ Constituinte, ministro da Fazenda de Floriano e de Prudente, presidente de S. Paulo e, a seguir, presidente da República, no famoso quadríênio de 1902-1906, outra vez presidente de S. Paulo, e, logo após, de novo eleito presidente da República, não tendo podido assumir o cargo por motivo de grave enfermidade, de que veiu a falecer.

Sem exagero, com a história politica da República se entrelaça a vida pública de Rodrigues Alves.

Admiremos sua visão de estadista, aquela que contrariando a opinião de sua provincia, fêlo opôr-se à primeira valorização do café - passo inicial, em falso, do que tem resultado todos os maleficios para a economia paulista; - aquela que, no governo da Republica, soube descobrir, a um tempo, Rio Branco e Oswaldo Cruz, Pereira Passos e Lauro Müller, com eles realizando a formidavel obra de integração do Brasil nos limites de suas fronteiras, e do Rio de Janeiro, na civilização, pela extinção da febre amarela" 